\title{
Botanical Pharmacognosy of the Fruit of Embelia ribes Burm. F
}

\section{Sudhakaran MV*}

UGC-Academic Staff College, University of Calicut, Malappuram-673635, Kerala, India

\begin{abstract}
Context: Embelia ribes Burm. $f$. is a large, scandent, struggling, medicinal climbing shrub belongs to the family Myrsinaceae. The plant is highly esteemed in Unani system of medicine as a powerful anthelmintic and it has been described as "Krimighna" in Ayurveda Classical text, Charaka Samhita. The species is highly specialized for the richness of biologically active dihydroxy benzoquinone, Embelin (2,5-dihydroxy-3-undecyl-p-benzoquinone) and reported to have the potentials of the anthelmintic, antifertility, antidiabetic, antidyslipidemic, and antioxidant activity.

Objectives: The present study was performed with the objectives of elaborating the macroscopic and histomorpho diagnostic profile of the berries of Embelia ribes and to analyze the powder microscopic peculiarities to support its botanical characterization.

Materials and methods: Macroscopic, microscopic evaluations and powder microscopy were carried out using the fresh and dried fruits of Embelia ribes.

Results: The globular berries were dull red to nearly black in color, with small beak- like projection of having the remains of style at the apex, and five lobed persistent calyxes in the mature fruits. Pericarp consisted of three distinct histological regions, the thin epidermis of the epicarp appeared warty, middle broad mesocarp consisted of large tabular parenchymatous tissues, sparsely distributed groups of fibrovascular bundles and stony cells. Druses crystals of calcium oxalate and simple, elliptical shaped starch grains were also found. The endocarp consisted of layers of brachy sclereids with pyramid like contour. Stony endocarp enclosed with single seed. The seeds were speckled with yellowish brown spots ('chitra-tandula' in Sanskrit), and bases were depressed inward intrusions of the perisperm and ruminate endosperm.
\end{abstract}

Keywords: Brachysclereids; Embelia ribes; Embryo; Druse-crystals; Pericarp; Perisperm; Ruminate- endosperm

\section{Abbreviations}

BRCL: Brachysclereids; CO: Cortex; CRL: Crystal; DRCRL: Druse Crystals; ENC: Endocarp; EPC: Epicarp; EPI: Epidermis; EBY: Embryo; END: Endosperm; MES: Mesocarp; PAC: Parenchyma Cell; PI: Pith; PH: Phloem; PRC: Pericarp; PRCRL: Prismatic Crystal; PRS: Perisperm; SED: Seed; SETC: Secretory Cell; STC: Stone Cell; STR: Starch Grain; TRI: Trichome; TSA: Testa

\section{Introduction}

Embelia ribes Burm. f. is a large, scandent, struggling, medicinal climbing shrub with elongated branchlets hanging over the support. The plant belongs to the family Myrsinaceae. The plant is distributed in India, Sri Lanka, Singapore and Malaysia. In India it is mainly found in Western Ghats and Eastern Himalayas, hilly regions of Arunachal Pradesh, Assam, Bengal, Orissa, Andhra Pradesh and Madhya Pradesh. This forest species have reported to be vulnerable in the Western Ghats of Tamil Nadu and Karnataka and at a lower risk in Kerala [1]. Embelia ribes is popularly known as Vidanga' or 'Vavding' (in Sanskrit) and Baberung (in Hindi), is highly esteemed in Unani system of medicine as a powerful anthelmintic and it has also been described as "Krimighna" in Ayurveda Classical text of Charaka Samhita [2]. However, the dried fruits of $E$. ribes Burm. f. was officially declared as the botanical source of the drug 'vidanga' by the Government of Indian in 1966 and was included in Indian Pharmacopeia [2,3]. E. ribes is one of the 32 medicinal plant species identified and earmarked in the 'Priority Species List' for cultivation by the National Medicinal Plant Board, Govt. of India, New Delhi. Among the many species in demand, E. ribes occupies a prime position as it constitutes major ingredients in many preparations of Indian System of Medicine and Homoeopathy (ISM\&H) and traditional herbal medicine [4]. According to Poojari [5], the vidanga is being used as an ingredient in about 75 different ayurvedic formulations. They include Vidangadi churna (antihelminthic, flatulence), Vidangadi yoga (anti-fertility), Pippalyadi yoga (contraceptive) Vidangsaravaleha (urinary diseases, leprosy and skin diseases) Kumariasava (seminal disorders, dementia, debility and liver disorders) Madhukasava (leprosy, leucoderma, blood disorders, dyspepsia) and Krmimudgar rasa (worm infestations, dyspepsia). Most of the biological actions of Embelia ribes have been ascribed to the active principle Embelin, a dihydroxy benzoquinone (2, 5-dihydroxy-3-undecyl-p-benzoquinone) and reported to have the potentials of the anthelmintic, antifertility, antidiabetic, antidyslipidemic, antioxidant and anticancer activities $[6,7]$. Because of high demand for the fruit of E. ribes, in domestic as well as international markets, coupled with the restricted geographic distribution of taxon and IUCN threatened status, inherent sterility of the seed, less yielding capacity, crude drug traders are subjected to the menace of the fruits of 26 species [8] are currently being traded under the name of vidanga. They include the fruits of Embelia tsjeriamcottam (Roem. and Schult.) A. DC., Myrsine africana Linn., and Piper cubeba Linn. F. They often bear morphological resemblances to vidanga, thus making almost impossible to distinguish them by sight. Since it is an important herbal remedy in traditional medicine,

*Corresponding author: MV Sudhakaran, UGC-Academic Staff College, University of Calicut, Calicut University P.O, Malappuram-673635, Kerala, India, Tel: +919447500125; E-mail: dr.sudhakaranvasu@gmail.com

Received September 07, 2015; Accepted September 24, 2015; Published September 28, 2015

Citation: Sudhakaran MV (2015) Botanical Pharmacognosy of the Fruit of Embelia ribes Burm. F. J Pharmacogn Nat Prod 1: 103. doi:10.4172/2472-0992.1000103

Copyright: (c) 2015 Sudhakaran MV. This is an open-access article distributed under the terms of the Creative Commons Attribution License, which permits unrestricted use, distribution, and reproduction in any medium, provided the original author and source are credited. 
Embelia ribes has extensively been investigated by various workers for its pharmacological [9-15], microbiological [16] phytochemical [17], genetics [18,19], morphological [2] and micropropagation studies [20]. Conversely, the existing literatures contain very little information on the description of structure of the fruit [2,8,17,21-23], most of them as such were concerning to the samples procured from the crude drug markets and on discrete plant parts of the fruit. Therefore a detailed botanical/pharmacogostical account of the fruit of vidanga is highly imperative which may provide critical evidence towards a refined knowledge on the taxon and demarcation of the fruit from its allied/ spurious/adulterant or substitute species. Thus the present study was undertaken with the objectives of elaborating the characteristics in detail and the fill the lacuna of our understanding about botanical pharmacognosy of the fruit of $E$. ribes, to a considerable extent.

\section{Materials and Methods}

\section{Plant material}

Embelia ribes Burm. f. is a large, perennial liana. The stem bark is studded with lenticels. Leaf: Simple, coriaceous, alternate, oblong, or narrowly obovate, margin is entire, apex acuminate, upper surface is glabrous, shiny and mature leave have scatted minute sunken, glanddotted. Inflorescence; terminal, paniculate raceme; Flowers are small, greenish to whitish pink colored. Sepals and petals are pentamerous, stamen is slightly exerted in staminate. Ovary: glabrous, stigma capitates. Fruit: globose berries with a small beak like persistent style at the apex (Figure 1 and 1a). The epicarp of the fruit is fragile, dull red or brownish black when dried with wrinkled surface, inside the endocarp enclosing a single seed. Seeds are speckled with yellowish brown spots.

\section{Methods}

E. ribes fresh aerial twigs bearing flowers and fruits at different development stages (Figure 1 and 1a) were collected from the natural habitat of forest at Ponmudi hills $\left(8.746^{\circ} \mathrm{N}\right.$ and $\left.77.127^{\circ} \mathrm{E}\right)$ of Thiruvananthapuram District of State of Kerala. Ponmudi (meaning 'Golden Crown/ Peak' in vernacular) situated at a geographical coordinate altitude of over $1100 \mathrm{~m}$ above sea level, which forms part of the Western Ghats mountain ranges of South India, enjoys a humid tropical climate and harbors high endemism of several plants species to the narrow mountain bands. The young drupaceous berries of $E$. ribes were green in color and ripened fruits were pinkish-red to black in color. The collected fruits were placed in sealed glass bottles, kept in a polyurethane box containing crushed ice, and brought to the laboratory and fixed in a solution prepared from formalin, glacial acetic acid and alcohol following the standard procedure of Johansen [24]. The plant was identified and authenticated with the help of the Flora of Presidency of Madras [25]. Fine hand sections of the fresh and dried fruits were taken using the razor blade and sections were stained with alcoholic Safranin (1\%), and mounted on glass slides in glycerin. Microphotographs of sections and powder analysis were made by using Olympus Microscope (Japan, Model CX 41) with CCD camera (DP 20). Images were concomitantly viewed and analyzed for pharmacognostic characteristics, and quantitative measurements were taken using Olympus Image-Pro Plus (version 5.1). The morphological details of intact drupe, whole pericarp and seed were analyzed using Olympus Stereomicroscope (Philippine, Model SZ 61) equipped with CCD camera (DP22) and microphotograph of the best representatives reveal characteristics in details, otherwise not visible in intact specimen were taken using the Olympus software (CellSens Entry 1.13). The fruit powder was cleared with absolute alcohol and mounted on glass slides for powder analysis. The descriptive terms of the anatomical features were used here as per Metcalfe and Chalk [26], Roth [27] and Sudhakaran [28-30].

\section{Results and Discussion}

\section{Macroscopic evaluation of fruit}

The fruit is an oval-shaped drupaceous berry varying in color from dull grey to red to nearly black; with a small beak- like projection, the remains of style at apex and sometimes in fruits, the pedicels along with persistent calyxes were present. Fruit was measured about $1850.87 \mu \mathrm{m}$ in length and $1773.04 \mu \mathrm{m}$ in diameter. The length and width of the pedicel were found to be about 595.6 and 199.3, respectively (Figure $1 \mathrm{~b}$ and 1c). The fruits have a faint spicy odor and a pungent and astringent taste.

\section{Microscopic evaluation of fruit}

The fruit originated from terminal panicles brought about differentiation with the formation of the pericarp. As the fruit develops, the pericarp differentiates morphologically into three zones: epicarp, mesocarp and endocarp. In young fruits at times during development, it was only possible to distinguish the epicarp and mesocarp (Figure 2 and $2 \mathrm{a}$ ) since the endocarp remains slightly differentiated. Stony endocarp became distinct when the fruit matures (Figure 3). In mature fruit the pericarp possessed a thin epicarp, a more or less fleshy parenchymatous mesocarp and stony endocarp. The epidermis of the epicarp consisted of a single continuous layer of rectangular cells, covered by thick cuticle. The cuticle thinned towards the end of fruit development, because of undergoing an accentuated reduction in thickness, and this reduction can in part be the result of the rapid expansion of the pericarp. The epicarp was relatively a thin part of the pericarp, appeared rough; surface wrinkled and the green color turned to become pinkish-red to black, when the fruits matured. The mesocarp

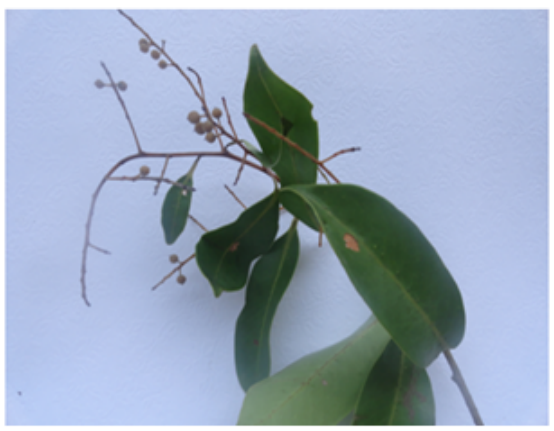

Figure 1: Embelia ribes Burm. f.: Twig with fruits.

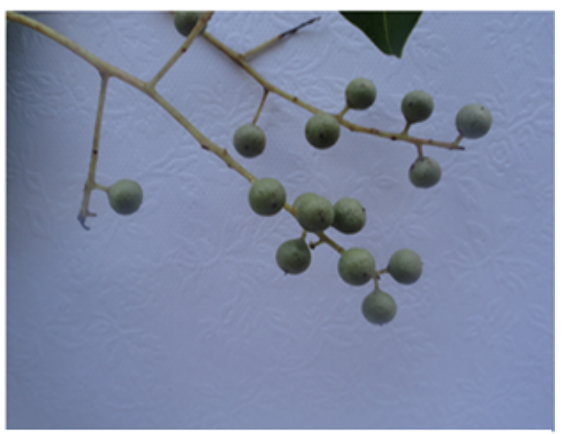

Figure 1a: Embelia ribes Burm. f.: Fruiting branches. 
Citation: Sudhakaran MV (2015) Botanical Pharmacognosy of the Fruit of Embelia ribes Burm. F. J Pharmacogn Nat Prod 1: 103. doi:10.4172/24720992.1000103

Page 3 of 8

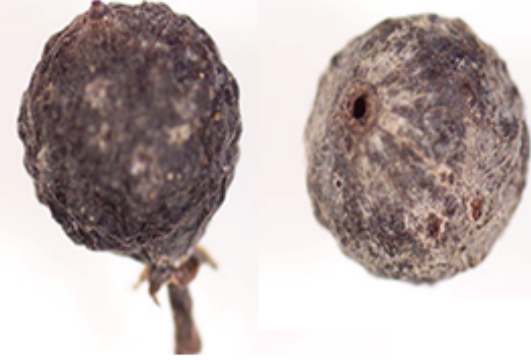

Figure 1b: Embelia ribes Burm. f.: Dried fruits- stereomicroscopic view (x2).

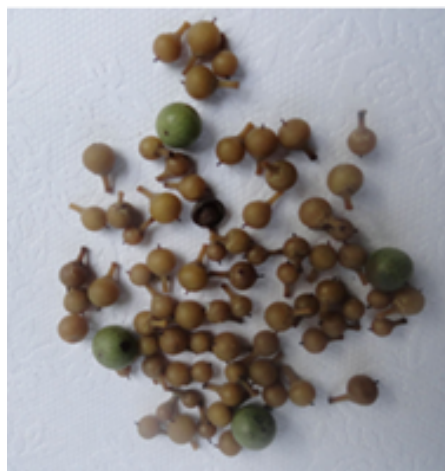

Figure 1c: Embelia ribes Burm. f.: Fresh fruits.

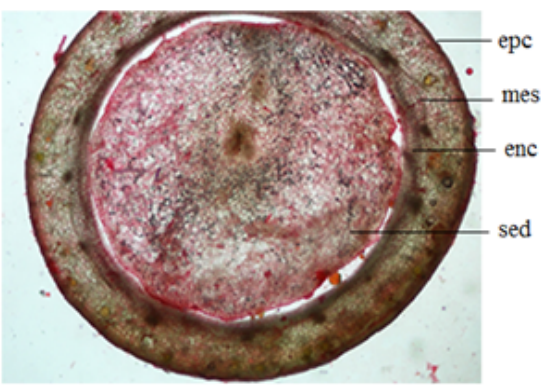

Figure 2: Embelia ribes Burm. f. (x2): Transverse section (T.S) of young fruit.

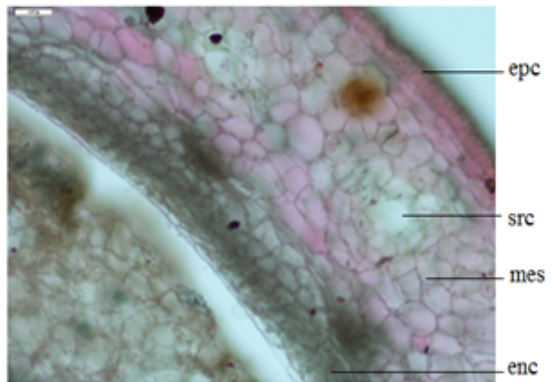

Figure 2a: Embelia ribes Burm. f. (x10): T.S of young fruit- a portion enlarged

was bizonate, which constituted the major part of the pericarp (Figure 3 and 3c). In matured fruits the parenchymatous tissues of the mesocarp contained several scatted patches of brachysclereids and fibrovascular bundles (Figure 3c and 3d), oil bodies, abundant deposition of starch grains were also found. Starch grains were found to be oval to elliptical in shape (Figure 3g). Parenchymatous tissues of external mesocarps were provided with several specialized secretory structures. These structures included: the schizogenous secretory cavities (Figure 2a), idioblasts or groups of idioblasts which produced crystalliferous cells. Crystalliferous cell contained a single druse crystal of calcium oxalate (Figure $3 \mathrm{~g}$ and $3 \mathrm{~h}$ ). Very often prismatic crystals of various sizes and shapes were also found embedded between the intervening walls of the parenchymatous cells of the mesocarp (Figure 3g). Fibro vascular tissues were seem to be occurred in the greater quantities in the internal mesocarpal tissues than the external tissues and they often found in association with brachysclereids in the matured fruit (Figure $3 \mathrm{c}$ and $3 \mathrm{~d}$ ). The function of brachysclereids and fibrovascular bundles could be to provide protection against mechanical, physiological and herbivorous stresses to the fruit. Ultrastructural observations and complementary chemical studies performed on specialized secretory cells of many members of the family Myrsinaceae, have reported to contained producing benzoquinones, a high valued secondary metabolite. The endocarp was stony composed of several internal layers of brachysclereids, arranged in a pyramidal fashion (Figure 3, 3a, 4 and $5 a)$. The radial extension of the layers of sclereids and sclereid density were found to be progressively tapering towards the apex from the base of the pyramid (Figure 3). The thickness of stony endocarp measured about $99.9 \mu \mathrm{m}$ to $100.2 \mu \mathrm{m}$ in general, while it reached approximately $153.5 \mu \mathrm{m}$ in area of sclereids having pyramidal protrusion (Figure 3, 3a and $3 \mathrm{c}$ ), this usage as it named by Warrier et al. [31]. The endocarp had heavily lignified, striated secondary wall with wide lumen and appeared brownish color in mature fruit (Figure $3 \mathrm{~b}, 3 \mathrm{e}$ and $3 \mathrm{f}$ ). The extensive lignifications of the endocarp provide it as the main mechanical protective layer of the pericarp. According to Roth [27], the typical drupes frequently possess sclerified endocarps and they are considered highly specialized fruits.

\section{Macroscopic evaluation of seed}

Each fruit possessed a single seed, which was reddish or brownish black in color, covered/speckled (Figure 6a) with yellowish brown

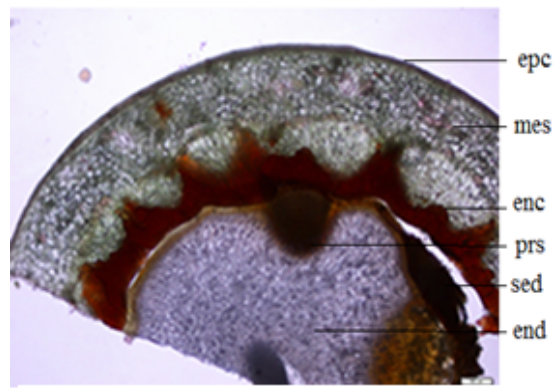

Figure 3: Embelia ribes Burm. f.: T.S of young fruit- a portion enlarged (x4)

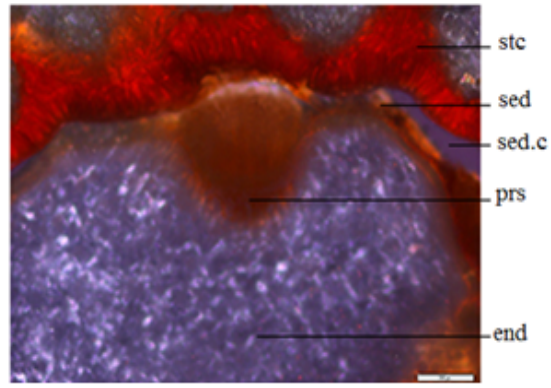

Figure 3a: Embelia ribes Burm. f.: T.S of mature fruit- a portion enlarged (x4) 
Citation: Sudhakaran MV (2015) Botanical Pharmacognosy of the Fruit of Embelia ribes Burm. F. J Pharmacogn Nat Prod 1: 103. doi:10.4172/24720992.1000103

Page 4 of 8

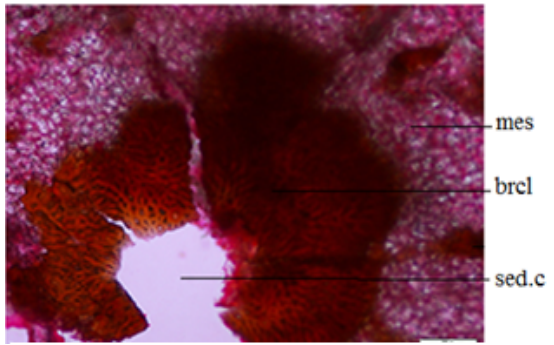

Figure 3b: Embelia ribes Burm. f.: T.S of mature fruit- a portion enlarged (x4).

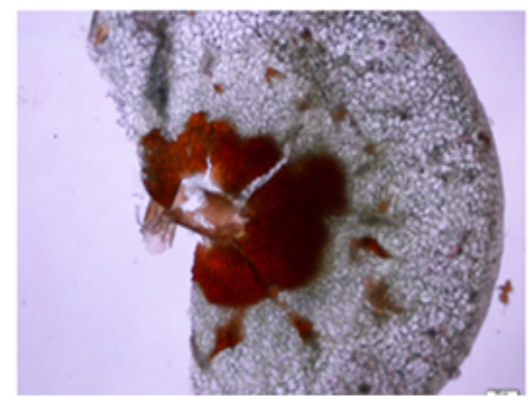

Figure 3c: Embelia ribes Burm. f.: Longitudinal section (L.S) of fruit passing through meso and endocarp $(x 2)$.

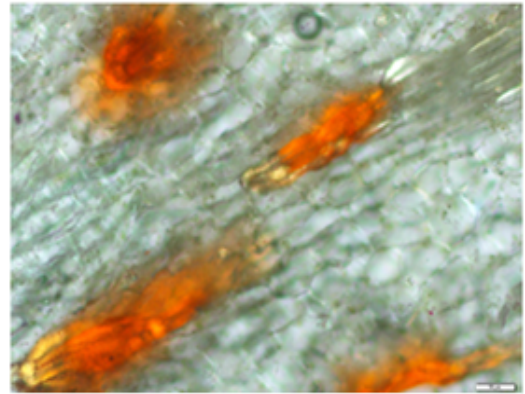

Figure 3d: Embelia ribes Burm. f.: L.S of fruit passing through mesocarp showing brachy sclereids.

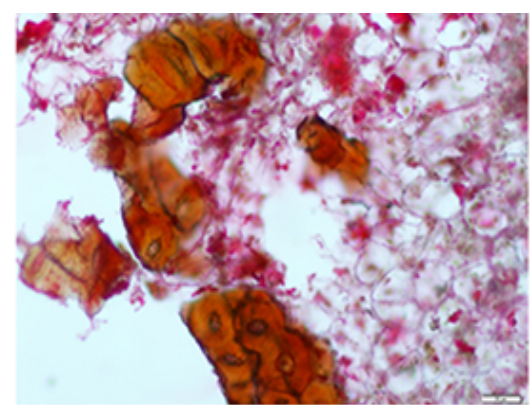

Figure 3e: Embelia ribes Burm. f.: T.S of fruit- mesocarp showing stone cells (x10).

spots (chitra-tandula). The seed occupied the major portion of the fruit (Figure 6, 6a and 6c). Seed was enclosed by the stony endocarp (Figure $6 \mathrm{~b}$ ). The active constituent, embelin primarily present in the area between seed and pericarp, which was quite clearly observable in the cross section of the fruit, without the aid of microscope. Seeds are aromatic and astringent taste with a slight pungency.

\section{Microscopic evaluation of seed}

According to Vijayarahavan and Prabhakaran [32] and Werker [33], the seeds of Myrsinaceae, are mostly originated from the anatropus, bitegmic ovule. Mature seed of E. ribes measured about $1258.3 \mu \mathrm{m}$ in length and $1167.9 \mu \mathrm{m}$ in diameter. Cross section of the seed appeared more or less circular outline, depression at the base exhibiting 3-4 inward intrusion of the perisperm (Figure 7). The seed was albuminous (Figure 7 and 7a) and trizonate, composed of seed coat, endosperm and embryo (Figure 6c). The seed coat was represented by distinctively multilayered one (Figure 6a). Below the integument a few cell layers of nucellus were compressed and seeds with irregular tegman producing invagination inwards (Figure 7), which protruded into the endosperm $(3 n)$ and endosperm appeared ruminate and retained the remnant of the maternal nucelluar tissues of diploid perisperm (2n). According to Werker [33], the perisperm could be the only nutritive tissues found in some dicotyledonous species, while in others in combination with endosperm, they form the nutritive tissues of the developing embryo. The endosperm of $E$. ribes occupied the major portion of the seed and consisted of several layers of cells with dense cytoplasm. The storage

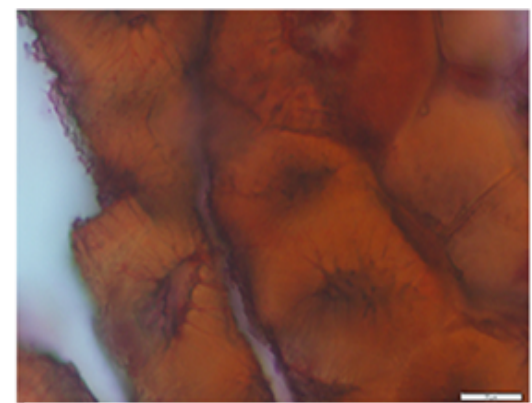

Figure 3f: Embelia ribes Burm. f.: T.S of fruit - stone cells of mesocarp (x40)

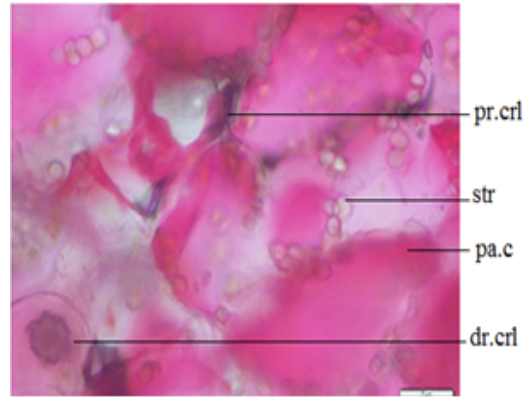

Figure 3g: Embelia ribes Burm. f. (x 10): T.S of fruit- a portion of mesocarp enlarged (x40).

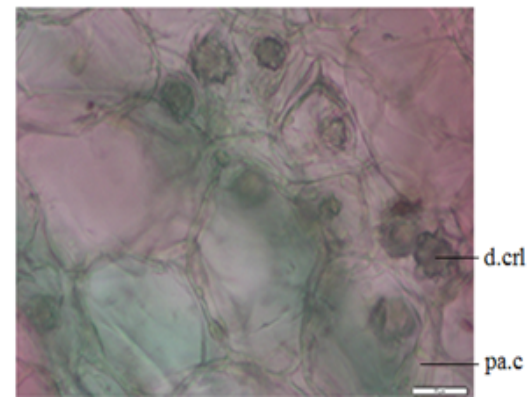

Figure 3h: Embelia ribes Burm. f. (x10): T.S of fruit- mesocarp showing druses crystals $(\mathrm{x} 10)$ 
Citation: Sudhakaran MV (2015) Botanical Pharmacognosy of the Fruit of Embelia ribes Burm. F. J Pharmacogn Nat Prod 1: 103. doi:10.4172/24720992.1000103

Page 5 of 8

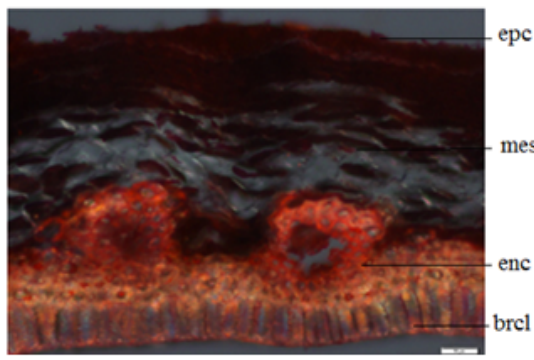

Figure 4: Embelia ribes Burm. f. (x 10): T.S of pericarp of dried fruit- polarized microscopy.

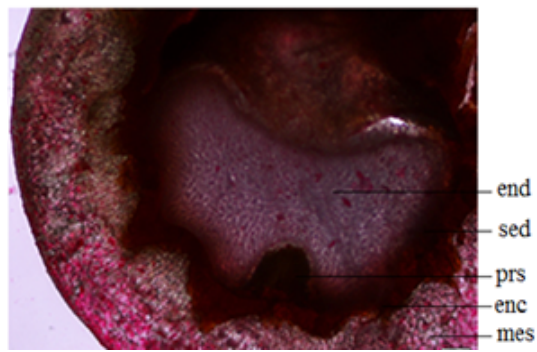

Figure 5: Embelia ribes Burm. f.: T.S of fruit passing through seed (x2).

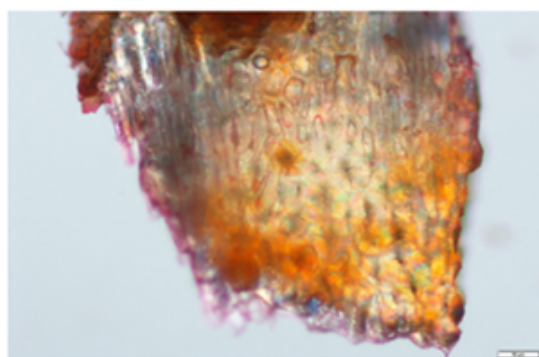

Figure 5a: Embelia ribes Burm. f. (x10): T.S of fruit- a portion of endocarp (brachy sclereids).

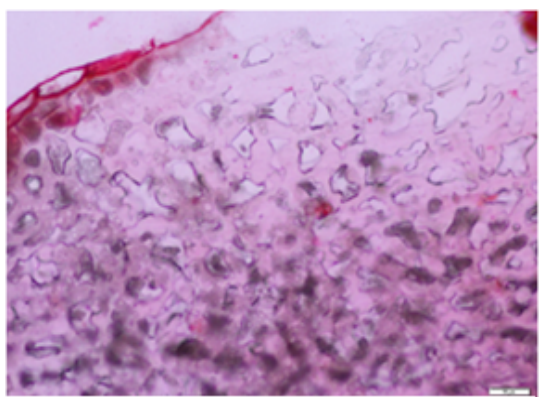

Figure 5b: Embelia ribes Burm. f. (x10): Cross section (C.S) of seed- a portion of endocarp enlarged.

proteins had accumulated in the tissues of endosperm (Figure $5 \mathrm{~b}$ and 5c) and also in embryo as protein bodies (aleurone grains) and they also contained minerals and crystals of calcium oxalate (Figure 7c). These protein reserves are necessary for the synthesis of various enzymes involved in starch digestion, primarily during seed germination. Endosperm seemed to be of labyrinthine type $[32,34]$, composed of a network of lobules. Axile embryo occupied relatively a small area of the endosperm volume, of an area of about $72046.2 \mu \mathrm{m}^{2}$; embryo was small, measured about $724.9 \mu \mathrm{m}$ in length and $127.1 \mu \mathrm{m}$ in diameter and appeared somewhat linear or straight, centrally located and embedded by the nutritive tissues of endosperm (Figure $6 \mathrm{~b}, 6 \mathrm{c}$ and $7 \mathrm{~b}$ ) and cotyledons were obscured, however generally most seeds are sterile.

\section{Microscopic evaluation of fruit pedicel}

Fruit pedicels were small cylindrical structures, with 4-5 lobed persistent calyxes attached to the dried berries (Figure $1 \mathrm{~b}$ and 6). Average pedicel length exceeds $600 \mu \mathrm{m}$ with diameters of about 200 $\mu \mathrm{m}$; which could support the fruit weighing more than $0.08 \mathrm{~g}$. The detachment of pedicel leaves a circular hollow scar on the globular ripened fruit (Figure 1b). Transverse sections of mature fruit pedicel

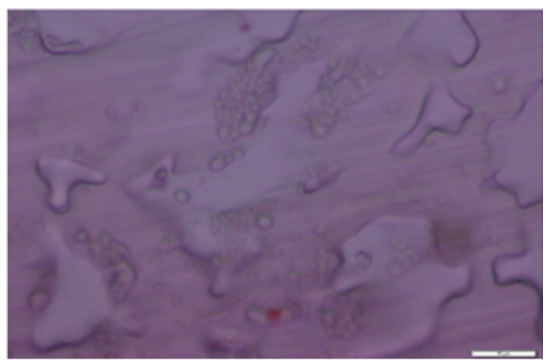

Figure 5c: Embelia ribes Burm. f.: C.S of seed- a portion of endocarp enlarged (x40).

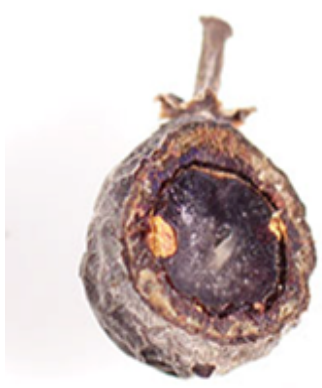

Figure 6: Embelia ribes Burm. f.: Stereomicroscopic view (x1): A fruit cuts open.

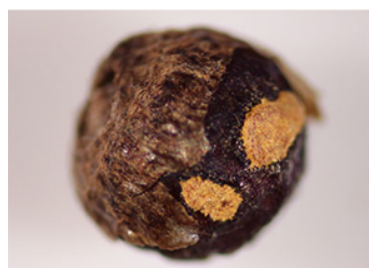

Figure 6a: Embelia ribes Burm. f.: Seed- stereomicroscopic view (x4)showing yellowish spots.

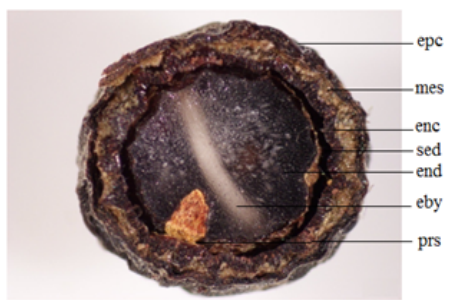

Figure 6b: Embelia ribes Burm. f.: Cross section of fruit- stereomicroscopy (x3). 
Citation: Sudhakaran MV (2015) Botanical Pharmacognosy of the Fruit of Embelia ribes Burm. F. J Pharmacogn Nat Prod 1: 103. doi:10.4172/24720992.1000103

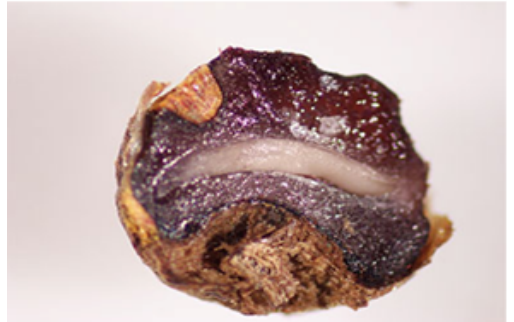

Figure 6c: Embelia ribes Burm. f.: Stereomicroscopy- seed showing testa, perisperm, endosperm and embryo (x4).

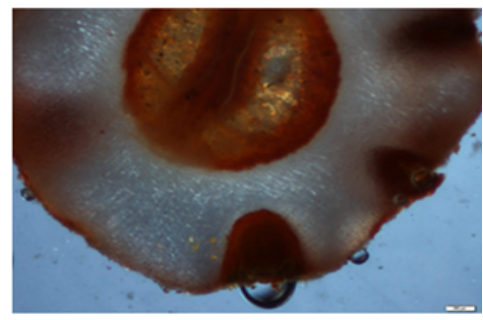

Figure 7: Embelia ribes Burm. f. (x2): C.S of dried seed- showing endosperm and embryo (x4).

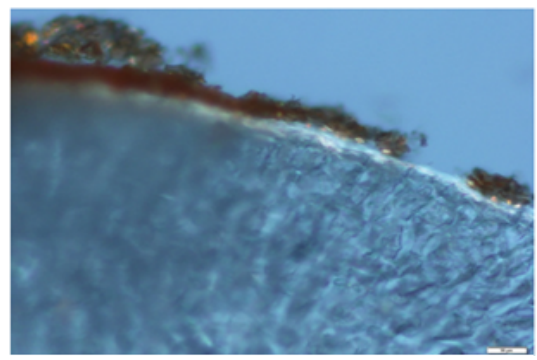

Figure 7a: Embelia ribes Burm. f. (x10): Polarised microscopic view of endosperm.

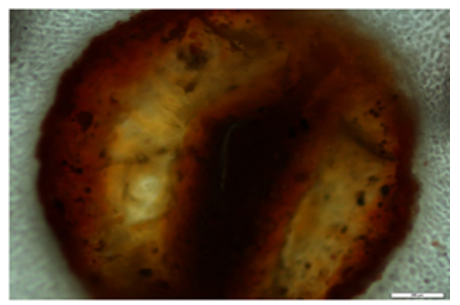

Figure 7b: Embelia ribes Burm. f. (x4): C.S of dried seed- a portion of enlarged showing embryo.

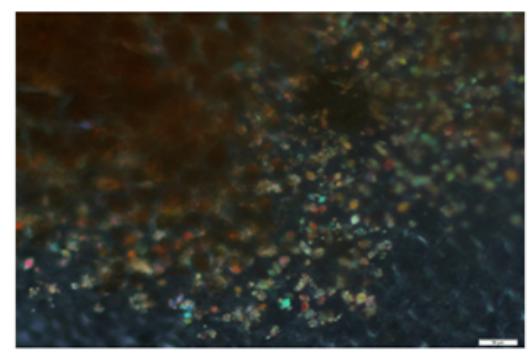

Figure 7c: Embelia ribes Burm. f. (x10): Polarised microscopic view of embryo showing crystals.

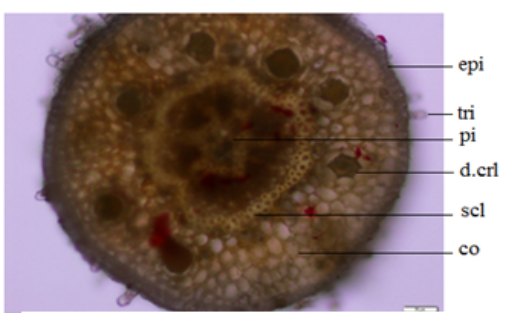

Figure 8: Embelia ribes Burm. f.: T.S of pedicel (x10).

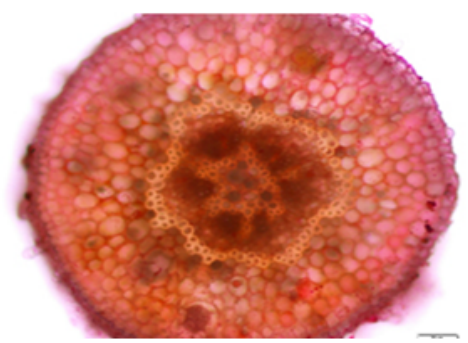

Figure 8a: Embelia ribes Burm. f.: T.S of pedicel (x10).

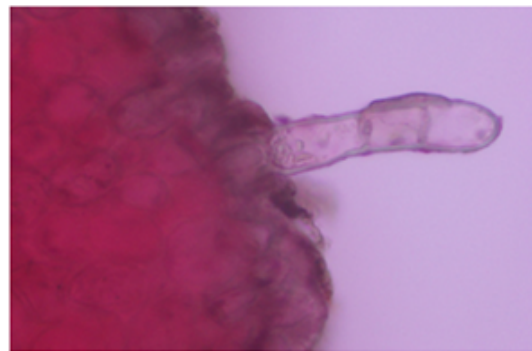

Figure 8b: Embelia ribes Burm. f.: T.S of pedicel - epidermal cells with trichome $(x 40)$.

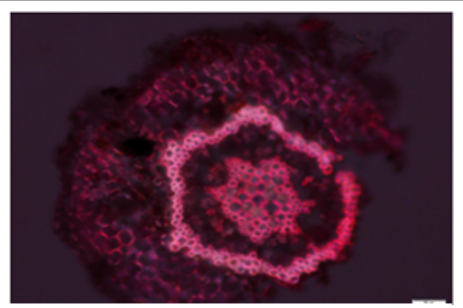

Figure 8c: Embelia ribes Burm. f.: T.S of pedicel - Polarised microscopic view (x10).

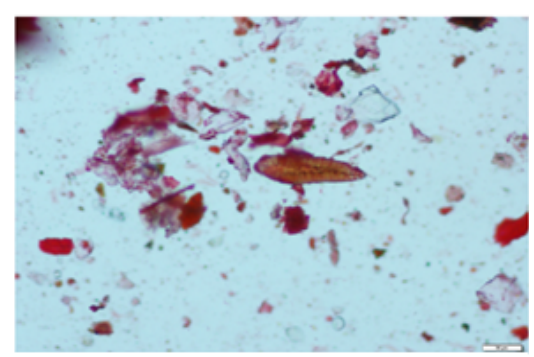

Figure 9: Embelia ribes Burm. f.: Powder microscopy of fruit showing sclereids, rystals and endosperm (x10). 


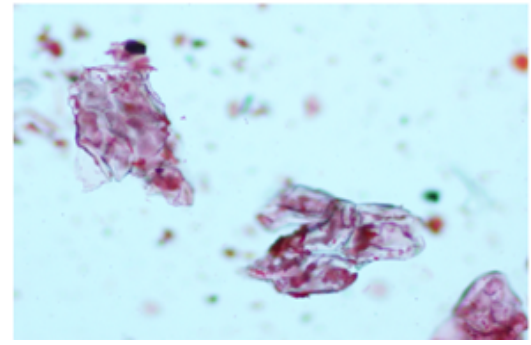

Figure 9a: Embelia ribes Burm. f.: Powder microscopy of fruit- endosperm cells $(\mathrm{x} 10)$.

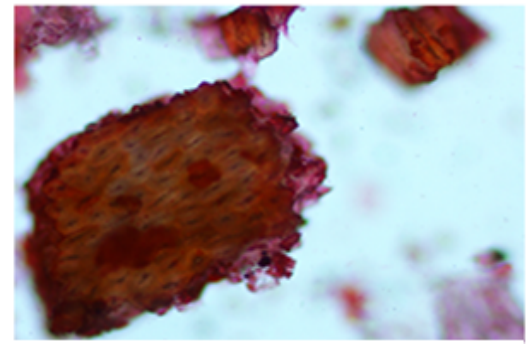

Figure 9b: Embelia ribes Burm. f.: Powder microscopy of fruit- stone cells (x10)

appeared more or less circular in outline with tissue organization of epidermis, cortex and pith (Figure $8 \mathrm{a}$ and $8 \mathrm{~b}$ ). Epidermis consisted of single layer of cubical cells covered with a partly thick cuticle, some of the epidermal cells were provided with uniseriate, threecelled trichome (Figure $8 \mathrm{a}$ and $8 \mathrm{~b}$ ). Individual trichome measured an average length of $80 \mu \mathrm{m}$ by width of $20 \mu \mathrm{m}$. Beneath the epidermis contained a lamellar collenchyma consisted of two to three rows of cells. The peripheral lamellar collenchyma represents the supporting tissue in pedicel and together with other peripherally arranged soft tissue layer it may influence the flexile rigidity of the pedicel. Cortical parenchyma formed the major portion of the tissues of pedicel. Mature fruit pedicel revealed a central pith parenchyma with thickened and partly lignified cell walls and cells contained druses crystals of calcium oxalate (Figure 8 and 8c). Vascular bundles were circularly arranged around the pith with a thin vascular cambium between the xylem and phloem. The phloem was enclosed by a flower-shaped closed ring of thick-walled sclereids (Figure 8c), followed by a thick cortex composed of isodiametric (polyhedral) parenchyma cells.

\section{Powder microscopy}

The dried fruits of $E$. ribes were analyzed for powder characteristics. The powder was dark green in color and has no characteristic taste and odor. Microscopic examination showed fragments of parenchymatous tissues of the mesocarp (Figure 9), calcium oxalate crystals (Figure 9a) and groups of stone cells (Figure 9b).

\section{Conclusion}

The results of the present study suggest that the documented morphological descriptors, delineated anatomical markers and powder characteristics could be effectively used for the identification and authentication of the berries of E. ribes Burm. f., from its allied, spurious, adulterant and substitute species.

\section{References}

1. Ravikumar K, Ved DK, Vijayasankar R (2000) Illustrated Field Guide of 100 Red Listed Medicinal Plants of Conservation Concern in Southern India. Foundation for Revitalisation of Local Health Traditions (FRLHT), Bangalore, India.
2. Patwardhan A, Mhaskar M, Joglekar A, Tadwalkar T, Wagh R, et al. (2014) Propagation and Cultivation Techniques of Embelia ribes (Vidanga). Daya Publishing House, New Delhi 237-256.

3. Mhaskar M, Joshi S, Chavan B, Jogleka A, Barve N, et al. (2011) Status of Embelia ribes Burm. f. (Vidanga), an important medicinal species of commerce from northern Western Ghats of India. Curr Sci 100: 547-552.

4. Chaudhari AB (2007) Endangered Medicinal Plants. Daya Publishing House, Delhi.

5. Poojari R (2014) Embelin-a drug of antiquity: Shifting the paradigm towards modern medicine. Expt Opin Investig Drugs 23: 427-444.

6. Bhandari U, Jain N, Pillai KK (2007) Further studies on antioxidant potential and protection of pancreatic $\beta$-cells by Embelia ribes in Experimental diabetes. Exp Diab Res 7: 1-6.

7. Harish GU, Danapur V, Jain R, Patel VM (2012) Endangered Medicinal Plant Embelia ribes Burm. f.-A review. Phacog J 4: 6-19.

8. Asadulla S, Ramandang and Rajasekharan (2013) Botanical Standardization of the Embeli Ribes Burm. f. and Possibilities of Species Substitute. Global J Med Res 13: 31-34.

9. Krishnaswamy M, Purushothaman KK (1980) Antifertility properties of Embelia ribes: (embelin). Indian J Exp Biol 18: 1359-1360.

10. Gupta S, Sanyal SN, Kanwar U (1989) Antispermatogenic effect of embelin, a plant enzoquinone, on male albino rats in vivo and in vitro. Contraception 39: 307-320.

11. Sreepriya M, Bali G (2005) Chemopreventive effects of embelin and curcumin against $\mathrm{N}$-nitrosodiethylamine/phenobarbital-induced hepatocarcinogenesis in Wistar rats. Fitoterapia 76: 549-555.

12. Xu M, Gui J, Fu H, Proksch P, Lin W, et al. (2005) Embelin derivatives and their anticancer activity through microtubule disassembly. Planta Med 71: 944-948.

13. Kumara SHM, Krishna V, Shankarmurthy K, Abdul RB, Mankani KL, et al. (2007) Wound healing activity of embelin isolated from the ethanol extract of leaves of Embelia ribes Burm. J Ethnopharmacol 109: 529-534

14. Nazish I, Ansari SH, Arora P (2012) Antiobesity actions of Embelia ribes. Phcog J 4: 73-80

15. Rajasekharan PE, Souravi K (2014) Ethnopharmacological Uses of Embelia ribes Burm. f. - A Review. J Pharma Biol Sci 9: 23-30.

16. Chitra M, Devi CSS, Sukumar E (2003) Antibacterial activity of embelin. Fitoterapia74: 401-403

17. Laddha KS, Ferreria GM (2013) Histochemical localization of embelin in fruits of Embelia ribes Burm and its quantification. Intl J Pharm Biosci Technol 1 : 16-19.

18. Devaiah KM, Venkatasubramanian P (2008) Genetic characterization and authentication of Embelia ribes using RAPD-PCR and SCAR marker. Planta Med 74: 194-196.

19. Gowda B, Chandrika, K, Prasanna KT, Kirana VC (2010) AFLP authentication of Embelia ribes Burm. f. and Embelia tsjeriam- cottam A. DC. Intl J Sci Nature 1: $58-60$.

20. Raghu AV, Unnikrishnan K, Geetha SP, Martin G, Balachandran I (2011) Plan regeneration and production of embelin from organogenic and embryogenic callus cultures of Embelia ribes Burm. f.-a vulnerable medicinal plant. In Vitro Cell Dev Biol (Plant) 47: 506-515.

21. Nambiar KVP, Jayanthi A, Sabu TK, Veneetha K (1996) Pharmacognostica studies on Embelia ribes Burm. f. Aryavaidyan 9: 220-230.

22. Ayurveda Pharmacopeoia of India (2001) Government of India, Ministry of Health and Family Welfare, Department of AYUSH. 1: 163-165.

23. Ibrahim Khan M, Ahmed A, Akram M, Mohiuddin E, Khan Usmanghani, et al. (2010) Monograph of Embelia ribes. African J Plant Sci 4: 503-505.

24. Johansen DA (1940) Plant Microtechnique. McGraw Hill, NewYork.

25. Gamble JS (1984) Flora of the Presidency of Madras. Bishen Singh Mahendra Pal Singh, India.

26. Metcalfe CR, Chalk $L$ (1985) Anatomy of the dicotyledons: Woodstructure and conclusion of the general introduction. (2nd edn) The Clarendon, Oxford, Great Britain. 
Citation: Sudhakaran MV (2015) Botanical Pharmacognosy of the Fruit of Embelia ribes Burm. F. J Pharmacogn Nat Prod 1: 103. doi:10.4172/24720992.1000103

27. Roth I (1987) Stratification of a tropical forest as seen in dispersal types: Tasks for vegetation science. Dr W. Junk Publishers, California, USA.

28. Sudhakaran MV (2012) Botanical pharmacognosy of Andrographis paniculata (Burm. f.) Wall. Ex. Nees. Phcog J 4: 1-10.

29. Sudhakaran MV (2012) Histo-morphological, fluorescent and powder microscopic characterization of Cissampelos pareira Linn. Phcog J 4: 57-68.

30. Sudhakaran MV (2014) Pharmacognostic and HPTLC Fingerprint Profile of the Root of Aristolochia indica Linn and Quantification of the Marker Compound. European Journal of Medicinal Plants 4: 1113-1124.
31. Nambiar VPK, Ganapathy PM (2001) Some Important Medicinal Plants of the Western Ghats, India: A Profile. Medicinal and Aromatic Plants Program in Asia (MAPPA), International Development Research Centre (IDRC) Canada, South Asia Regional Office. New Delhi, India : 398.

32. Vijayaraghavan MK, Prabhakar K (1984) The Endosperm. BM Johri, SpringerVerleg, Berlin, Germany.

33. Werker E (1997) Seed Anatomy. Gebrunder Borntraeger, Berlin, Germany.

34. Floyd DK, Friedman WF (2000) Evolution of Endosperm Development Patterns among Basal Flowering Plants. Intl J Plant Sci. 